\title{
CONTROL OF T CELL RESPONSES, TOLERANCE AND AUTOIMMUNITY BY REGULATORY T CELLS: CURRENT CONCEPTS
}

\author{
Pavel Chrobák \\ Institute of Clinical Research of Montreal, Montreal, Quebec, Canada: Molecular Biology Unit
}

\begin{abstract}
Summary: Regulatory $\mathrm{T}$ cells have emerged as an important mechanism of regulating tolerance and $\mathrm{T}$ cell responses. $\mathrm{CD} 4^{+}$ regulatory $\mathrm{T}$ cells can be divided into two main groups, natural regulatory $\mathrm{T}$ cells, which express high levels of CD25 on their cell surface and phenotypically diverse adaptive (antigen induced) regulatory $\mathrm{T}$ cells. Natural regulatory $\mathrm{T}$ cells are made in the thymus, and require strong costimulatory signals for induction and maintenance, express a transcription factor called Foxp3, and function by a largely unknown mechanism. Adaptive (antigen induced) regulatory $\mathrm{T}$ cells are made by sub-optimal antigenic signals in the periphery, in the presence of immunosuppressive cytokines, often in special circumstances, such as chronic viral infections or after mucosal administration of antigen, and rely on cytokines such as IL-10 and TGF- $\beta$ for suppression. Regulatory T cells offer a great potential for the treatment of autoimmune diseases and during transplantation.
\end{abstract}

Key words: Regulatory T cells; Tolerance; Autoimmunity; Transplantation; Infection

\section{Introduction}

$\mathrm{T}$ lymphocyte populations are maintained under tight homeostatic regulation, ensuring maintenance of sufficient and stable cell numbers, with distinct population ratios, and with a proper localization within distinct anatomical compartments. Lymphocytes have an ability to respond and eliminate foreign antigens presented to them by antigen presenting cells, and to remain tolerant to self-antigens. At times mechanisms which ensure this regulation are disrupted, affecting $\mathrm{T}$ cell numbers and functions, such as seen for example dramatically in human HIV infection, after chemotherapy or following hematopoetic stem cell transplantation. Inappropriate $\mathrm{T}$ cell activation can even lead to an attack on host tissues, such as seen in GVHD or autoimmune diseases. T cell tolerance is primarily ensured during development of $\mathrm{T}$ cells in the thymus, where potentially autoreactive $T$ cells are eliminated during the process of negative selection. This is known as central tolerance. Even though the molecular mechanisms of central tolerance induction are still not fully explained, it has been demonstrated that failed induction of central tolerance due to defective negative selection can lead to autoimmunity $(38,56)$ under certain circumstances. However, not all $\mathrm{T}$ cells specific for self-antigens are eliminated in the thymus and self-antigen specific $\mathrm{T}$ cells are often present in peripheral lymphoid organs of healthy individuals, where they can be readily detected. However, these self-specific T cells usually do not cause autoimmunity, even though they might be specific for autoantigens associated with the development of autoimmune disease $(6,51)$, a fact that implies efficient peripheral control. It is clear that such efficient control involves different cell types, which often collaborate and interact with each other through different pathways. In the 1970s a concept of T suppressor cells emerged, suggesting that $\mathrm{T}$ cells police themselves in ensuring self-tolerance in the periphery, a concept which was later rejected based on the lack of mechanisms available to explain the cellular and molecular nature of the suppressor concept. Only recently has the concept been revised and reintroduced, with recent work expanding our understanding of the role and mechanism of action of regulatory $T$ cells. Here, we summarize current concepts of the regulatory $\mathrm{T}$ cell phenomena, focusing on $\mathrm{CD}^{+}$regulatory $\mathrm{T}$ cells, starting with the definition of a regulatory $\mathrm{T}$ cell, we discuss the classification of the great multitude of $\mathrm{T}$ cells exhibiting regulatory function, as well as how these cells are generated and maintained. We also mention the role of dendritic cell (DC) populations, and discuss the mechanisms and pathways implicated in regulatory $\mathrm{T}$ cell mediated immunoregulation. We end with a summary on their potential therapeutic use in the context of autoimmune diseases and transplantation. 


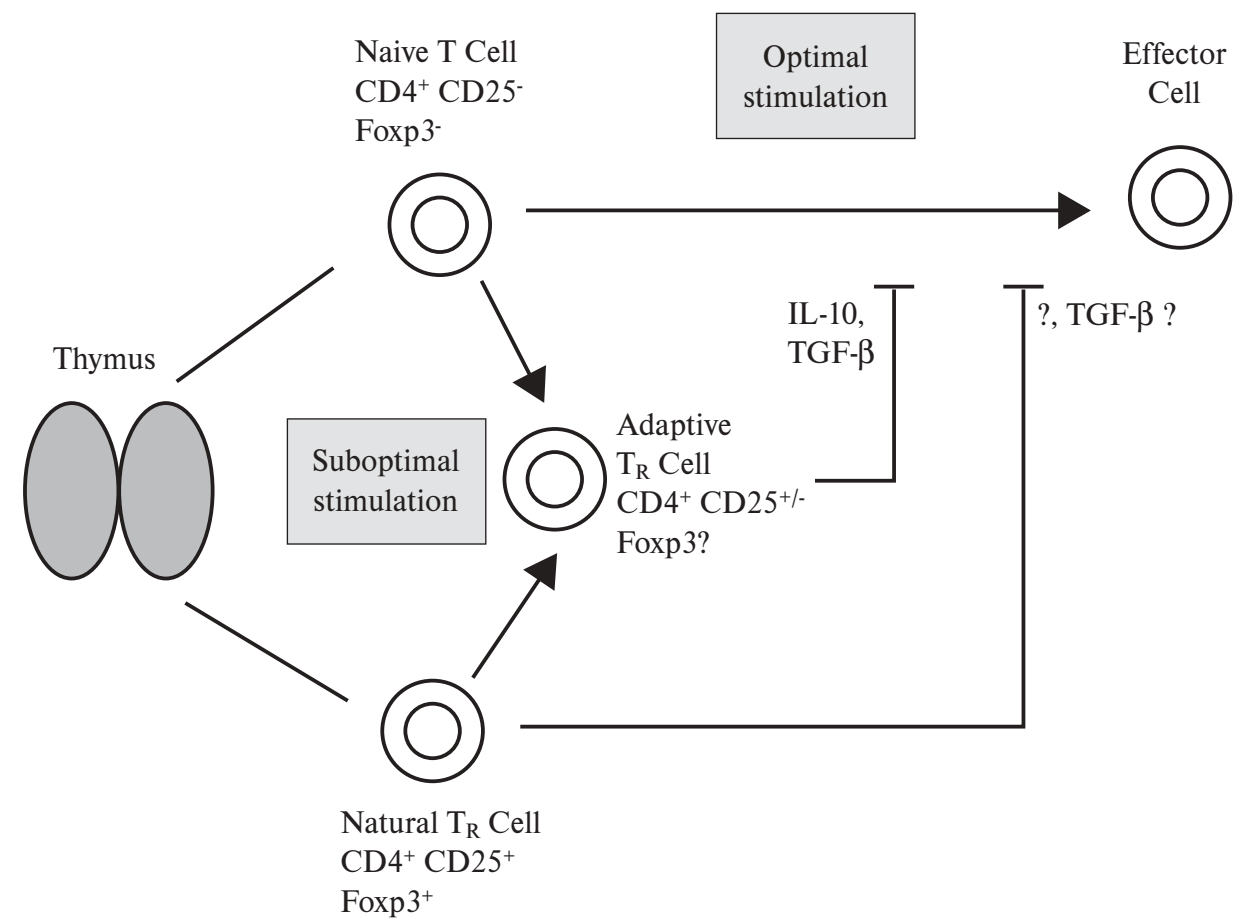

Fig. 1: Origins and relationship between regulatory $T$ cell $\left(T_{R}\right)$ populations.

Thymic development results in the generation of natural $\mathrm{CD} 4^{+} \mathrm{CD} 25^{+} \mathrm{TR}$ cells and naive $\mathrm{CD} 4^{+} \mathrm{CD} 25^{-} \mathrm{T}$ cells. Stimulation of $T$ cells in the periphery under tolerogenic conditions leads to the maturation of adaptive $T_{R}$ cells, while stimulation under optimal conditions leads to the generation of effector cells. Adaptive $T_{R}$ cells suppress effector immune repsonses mainly by a cytokine (IL-10, TGF- $\beta$ ) dependent mechanism, while natural $\mathrm{T}_{\mathrm{R}}$ cells function by a largely uncharacterized mechanism.

\section{Mechanisms Involved in Maintenance of Peripheral T Cell Tolerance}

Although not a focus of this review, we should mention briefly the mechanisms involved in maintaining peripheral tolerance of $\mathrm{T}$ cells. Firstly, encounter with self-antigen in the absence of proper stimulatory conditions can lead to a state of intrinsic functional inactivation, termed anergy (recently reviewed in 50), where a lymphocyte remains alive for an extended period of time but is hyporesponsive. Interestingly, there is a clear link between anergy and T cell regulatory function $(39,50)$. Secondly, autoreactive $T$ cells may be eliminated by apoptosis during activation induced cell death (AICD). Thirdly, even though T cells might become fully activated, operational tolerance might still be maintained, when $\mathrm{T}$ cell cytokine production or their trafficking properties are such that damage is avoided, a mechanism called phenotype skewing. The fourth mechanism is called ignorance, where a self-antigen specific $\mathrm{T}$ cell remains tolerant either because the self-antigen is sequestered in the body, or because it is in such low amounts that a $\mathrm{T}$ cell response is not triggered. This mechanism is thought to operate relatively less frequently. Finally, such regulation may be induced and actively maintained by distinct regulatory cell populations.

\section{Definition and Populations of Regulatory $\mathbf{T}$ Cells}

Regulatory $\mathrm{T}$ cell might be defined by their role in maintaining $\mathrm{T}$ cell homeostasis, peripheral tolerance, and in the regulation of immune responses. However, depending on the circumstances, their action may potentially be either beneficial or detrimental to the host (Table 1). The existence of regulatory $\mathrm{T}$ cells, originally called suppressor $\mathrm{T}$ cells, was for the first time shown by R.K. Gershon and K. Kondo in 1971 (25). Due to the lack of understanding of the phenomenon, caused by the lack of techniques available at the time, as well as due to certain erroneous conclusions

Tab. 1: Roles of regulatory $\mathrm{T}$ cells.

\section{Positive}

- Maintain T-cell homeostasis

- Maintain peripheral tolerance

- Prevent transplantation immune reactions (rejection and GVHD)

- Prevent hypersensitivity and allergy

\section{Negative}

- Suppress tumor immunity

- Suppress immunity to infection 
Tab. 2: Distinct regulatory $\mathrm{T}$ cell subsets other than $\mathrm{Th} 1 / \mathrm{Th} 2 \mathrm{CD} 4^{+} \mathrm{T}$ cells.

\begin{tabular}{|c|c|c|}
\hline A. & $\mathrm{CD4}^{+}$ & Circumstances of Regulation \\
\hline & a. $\mathrm{CD}^{+} \mathrm{CD} 25^{+} \mathrm{CD} 45 \mathrm{RB}^{\text {low }}$ & $\begin{array}{l}\text { day- } 3 \text { thymectomy autoimmunity } \\
\text { autoimmune colitis in SCID mice reconstituted with CD } 45 \mathrm{Rb}^{\text {hi }} \mathrm{T} \text { cells }\end{array}$ \\
\hline & b. $\mathrm{CD}^{+} \mathrm{CD} 25^{+} \mathrm{CD} 6 \mathrm{~L}^{+}$ & $\begin{array}{l}\text { allograft tolerance } \\
\text { autoimmunity after adult thymectomy plus irradiation } \\
\text { non-obese diabetic (NOD) mice }\end{array}$ \\
\hline & c. $\mathrm{CD}^{+} \mathrm{CD} 25-$ & $\begin{array}{l}\text { autoimmune colitis in SCID mice reconstituted with CD45Rb } \\
\text { allograft tolerance }\end{array}$ \\
\hline & d. $\mathrm{T}_{\mathrm{H}} 3$ & mucosal Ag specific \\
\hline & e. $\operatorname{Tr} 1$ & mucosal (nasal) peptide \\
\hline B. & $\mathrm{CD}^{+}$ & experimental autoimmune encephalomyelitis (EAE) \\
\hline C. & TcR $\alpha \beta^{+}$CD4-CD8- & allograft tolerance \\
\hline D. & NK-T & autoimmune diabetes \\
\hline E. & $\gamma \delta-\mathrm{T}$ & $\begin{array}{l}\text { cutaneous inflammation } \\
\text { autoimmune diabetes }\end{array}$ \\
\hline
\end{tabular}

reached, the field was later abandoned. Recently however, a new era of interest began with observations by Sakaguchi and colleagues $(3,49)$ on the ability of $\mathrm{CD}^{+} \mathrm{CD}^{+} 5^{+}$regulatory $\mathrm{T}$ cells to prevent autoimmunity caused by thymectomy. The list of $\mathrm{T}$ cell subsets with demonstrated regulatory function is quite extensive (Table 2). This in fact presents quite a challenge to the understanding of regulatory $\mathrm{T}$ cell function. The $\mathrm{CD} 4^{+}$regulatory $\mathrm{T}$ cell group represents a heterogeneous group, with regards to their cell surface phenotype, origin, as well as cytokine production profile, and it appears that some of the subsets are related developmentally and/or are associated functionally. This is in addition to the fact that helper CD4 T cells of distinct cytokine production profile patterns, T helper type 1 (Th1) or 2 (Th2), can also regulate immune responses. Recently, Bluestone and Abbas (11) described a classification of these populations into spontaneously appearing 'natural' regulatory $\mathrm{T}$ cells (CD25 expressing $\mathrm{CD} 4^{+}$subset, and perhaps also NK-T cells and $\gamma \delta$ T cells), the role of which might be maintenance of peripheral tolerance, and 'adaptive' regulatory $\mathrm{T}$ cells which arise as a result of encounters with antigen in the periphery in the right milieu, and express variable cell surface markers. The usual role of these 'adaptive' cells might be perhaps more to downregulate adaptive immune responses.

\section{Natural Regulatory T Cells}

Natural regulatory $\mathrm{T}$ cells are cell populations normally present in healthy hosts, including in man, which are crucial for the maintenance of peripheral self-tolerance. The $\mathrm{CD} 4^{+} \mathrm{CD} 25^{+}$population seems to be the major subset $(6,11)$, although other T cells, such as NK-T cells and $\gamma \delta-\mathrm{T}$ cells, likely belong to this category as well. The $\mathrm{CD} 4^{+} \mathrm{CD} 25^{+}$regulatory $\mathrm{T}$ cells normally constitute $5-10 \%$ of peripheral $\mathrm{CD} 4^{+} \mathrm{T}$ cells, express high levels of CD25 (the alpha chain of the IL-2 receptor). However, CD25 is also expressed by $\mathrm{T}$ cells undergoing activation (although regulatory $\mathrm{T}$ cells may have a higher level of CD25 expression). Even though other markers can be used for detection, such as cytotoxic T-lymphocyte antigen 4 (CTLA-4), glucocorticoid-induced tumor-necrosis factor receptor family-related gene (GITR), CD103 ( $\alpha_{E} \beta_{7}$ integrin), and low expression of CD45RB $(6,11)$, none of these markers is specific for regulatory cells alone, making their detection challenging.

The $\mathrm{CD} 4^{+} \mathrm{CD} 25^{+}$regulatory $\mathrm{T}$ cells seem to be naturally generated during $\mathrm{T}$ cell development in the thymus, where they are generated under high avidity interactions when a developing thymocyte escapes negative selection $(10,11,54)$. These cells might be perhaps selected by ectopically expressed peripheral self-antigens presented by certain specialized stromal populations, such as the medullary epithelial cells (MEC). The high levels of CD25 expression on their surface suggest that these cells might be kept under constant activation by self-antigens (41).

It has been shown that their generation as well as maintenance requires costimulatory signals delivered through CD28, since they are not made in CD28 deficient mice (11) and that it also requires IL-2 (2). Even though strong signals are required for their generation, they do not proliferate in-vitro (57), however they are able to undergo homeostatic expansion when transferred into lymphopenic hosts (24). Their importance can be documented in several different systems. For example, thymectomy in mice between days three and five after birth leads to the development of a multiorgan autoimmune syndrome, which includes autoimmune thyroiditis, gastritis, oophoritis, orchitis and a wasting disease which can be prevented by the administration of $\mathrm{CD} 4^{+} \mathrm{CD} 25^{+} \mathrm{T}$ cells $(3,46)$. It is argued that thymectomy at this age prevents production of thymic regulatory $\mathrm{T}$ cell subsets, while sufficient $\mathrm{T}$ cell production has already occurred to ensure $\mathrm{T}$ cell mediated functions, such as delayed type hypersensitivity, allograft rejection, and help for $\mathrm{Ab}$ production. Even adult thymectomy followed by irradiation in certain rat strains results in a similar autoimmune syndrome, which again can be prevented by the admini- 
stration of $\mathrm{CD}^{+} \mathrm{CD} 25^{+}$cells (22). Also, severe combined immunodeficient (SCID) mice reconstituted with CD45RB ${ }^{\text {hi }}$ cells develop autoimmune colitis, which can be prevented by injecting $\mathrm{CD}^{+} \mathrm{CD} 25^{+} \mathrm{CD} 45 \mathrm{RB}^{\text {lo }} \mathrm{T}$ cells. However $\mathrm{CD} 25^{-}$regulatory $\mathrm{T}$ cells show some protective role in this model as well, albeit not as potent (reviewed in 52). While these experiments demonstrate regulatory $\mathrm{T}$ cell function, they share as a drawback the fact that such function occurs under lymphopenic conditions, where $\mathrm{T}$ cell homeostasis is dramatically changed by feedback mechanisms driving residual $\mathrm{T}$ cells toward regenerative homeostatic expansion. It is possible that regulatory $\mathrm{T}$ cells under these conditions simply outcompete the pathogenic T cells due to their high affinity for self-antigen. This scenario would not apply under normal non-lymphopenic circumstances, and therefore experimental models without lymphopenia are very valuable for the dissection of regulatory $\mathrm{T}$ cell function. This can be demonstrated for example in T cell receptor (TCR) transgenic mice, where the TCR transgene encodes a diabetogenic specificity. These mice do not develop diabetes, because transgenic $\mathrm{T}$ cells are kept under control by regulatory $\mathrm{T}$ cells generated in these mice by endogenous rearrangement of the TCR in about $10 \%$ of peripheral T cells. When endogenous rearrangement is stopped, by breeding the mice on a recombination activating gene (RAG) deficient background, the mice progress to diabetes. Similar models exist for autoimmune encephalitis (all reviewed in 6).

Recently, natural regulatory activity in mouse $\mathrm{CD}^{+}$ $\mathrm{CD} 25^{+} \mathrm{T}$ cells has been shown to require a transcription factor called Foxp3 (forkhead/winged-helix protein) (reviewed in 48). Interestingly, even $\mathrm{CD} 4^{+} \mathrm{CD} 25^{-}$and $\mathrm{CD} 4^{-} \mathrm{CD} 8^{+}$ $T$ cells with no regulatory activity have become suppressive after ectopic expression of Foxp3, demonstrating that this transcription factor is both sufficient and necessary to induce regulatory function in T cells, and the importance of this transcription factor can be documented in mice deficient in Foxp3, which develop an autoimmune syndrome. Interestingly, mutations in the human homologue of Foxp3 lead to IPEX syndrome (Immune dysregulation, polyendocrinopathy, enteropathy, and X-linked inheritance) characterized by global immune dysregulation, with autoimmune endocrinopathy, early onset type 1 diabetes and thyroiditis, and in some cases manifestation of severe atopy, including eczema, food allergy and eosinophilic inflammation (48). Foxp3 seems to be a specific marker of natural regulatory $\mathrm{T}$ cells, it has not been found in naive and activated $\mathrm{T}$ cells without regulatory activity, however the precise molecular role of Foxp3 is not clear. It remains to be seen, if this factor is also associated with regulation by adaptive regulatory $\mathrm{T}$ cells.

\section{Adaptive (Antigen-induced) Regulatory T Cells}

It is also clear that regulatory $\mathrm{T}$ cells may be generated in-vivo or in-vitro from $\mathrm{CD} 4^{+} \mathrm{CD} 25^{-} \mathrm{T}$ cells without regulatory function or alternatively from natural $\mathrm{CD} 4^{+} \mathrm{CD} 25^{+}$ regulatory $\mathrm{T}$ cells in the periphery following antigenic stimulation $(11,28,62)$. Their development seems to be favored by antigen presentation in a suboptimal 'tolerogenic' form, such as by immature dendritic cells (DC), or perhaps by populations of specialized but suppressive dendritic cells (63), in the presence of insufficient costimulatory signals and certain immunosuppressive cytokines, namely IL-10 or IL-4 $(11,13,28,58,62)$, so in quite different circumstances from 'natural' regulatory T cells, which, as mentioned above, require a strong, high affinity signal with costimulation. Protocols, which induce anergy in-vivo and in-vitro have resulted in the generation of regulatory $\mathrm{T}$ cells, especially in the presence of IL-10 $(1,3,14,28,34,58)$. The anergy state of these populations may be different from usual adaptive anergy, because, for example, it is maintained even in the absence of antigen, whereas adaptive anergy normally decays under these conditions.

Phenotypic characteristics of these populations are variable, they may belong to different lineages, including TcR- $\alpha \beta$ and $\gamma \delta \mathrm{T}$ cells. Just as with natural regulatory T cells, the CD $4^{+}$TcR- $\alpha \beta$ T cell subset represents an important population of the antigen-induced regulatory $T$ cells, and they often express CD25 (11), and share other markers with natural $\mathrm{CD} 25^{+}$regulatory $\mathrm{T}$ cells, which brings up the question of how these populations are related developmentally. Adaptive regulatory $\mathrm{T}$ cells generally produce immunosuppressive cytokines, such as IL-10, and TGF $\beta$, which, as mentioned above, also promote their development. They can in fact be divided based on cytokine production into certain subpopulations, such as IL-10 producing $T_{r} 1$ cells $(27,28,35)$, TGF- $\beta$ producing $\mathrm{T}_{\mathrm{H}} 3$ cells $(64,70)$, and IL-4 producing $\mathrm{T}_{\mathrm{H}}$ 2-like cells (31).

It is quite interesting to consider further the circumstances under which these cells are generated. They may develop spontaneously when triggered by autoantigen. For example, $\mathrm{CD} 25^{+} \mathrm{CD} 62 \mathrm{~L}^{+}$regulatory $\mathrm{T}$ cells isolated from diabetes prone non-obese diabetic (NOD) mice show regulatory activity when transfered with pathogenic $\mathrm{T}$ cells into NOD/SCID mice (37). However, they are not able to protect congenic NOD recipients against diabetes without the recipients' manipulation, e.g. by irradiation (12). On the other hand, mucosal administration of antigens, including orally administered insulin generates very potent regulatory $\mathrm{T}$ cells, the phenotype of which varies with the route and form of administration, which are able to protect against disease even in immunocompetent non-lymphopenic hosts $(5,17,31,69)$. It is likely that mucosal sites, where environmental and bacterial antigens are routinely encountered favor regulatory $\mathrm{T}$ cell development due to the milieu of mucosal DC populations, which have been described to preferentially induce regulatory $\mathrm{T}$ cells (65) and due to the presence of cytokines, such as IL-10 and TGF- $\beta$.

Alternatively, predominantly $T_{R} 1$ cells secreting IL-10 are induced during infections, sometimes triggered by specific pathogen associated antigens, and lead to immunosuppression. This has been demonstrated with viruses, such 
as the mouse Friend leukemia virus (32), EBV virus in humans (42), and during infections with other pathogens $(9,44)$ in mice. The consequence of such immunosuppression might be detrimental, by suppressing the elimination of the pathogen, serving as an immune evasion mechanism (45) and perhaps contribute to the establishment of viral latency. Interestingly, immature DC populations have been recently described in a murine AIDS model, where pathology is induced by the expression of the HIV nef protein (47), raising the possibility that regulatory T cells may play a role in HIV associated immunodeficiency.

Finally, these cells can be induced by i.v. administration of antigen. For example, antigen-specific tolerance to allografts can be established by administration of alloantigen by this way, especially in the context of other immunosuppressive regimen, and can subsequently be transferred to naive animals by $\mathrm{CD} 4^{+} \mathrm{T}$ cells (13).

In summary, not every self-specific $\mathrm{T}$ cell needs to be harmful, but in-fact the inefficient negative selection in the thymus might generate self-specific regulatory or potentially regulatory $\mathrm{T}$ cells, which are turned on in the periphery in the right circumstances (antigenic and inflammatory environment, cytokines, dendritic cells). Even though the adaptive regulatory $\mathrm{T}$ cells share the function of tolerance maintenance with natural regulatory $T$ cells, it may be the inflammatory conditions under which they are generated and triggered that separate them. The natural regulatory $T$ cells might operate more in a non-inflammatory environment, while they might acquire the characteristics of antigen induced regulatory $\mathrm{T}$ cells in an inflammatory setting (recently reviewed in 11). Further the fact that antigens induce either an effector or a regulatory $\mathrm{T}$ cell indicates that the immune system needs to achieve a fine balance between immune control of infection, tumors and autoimmunity. How this balance is achieved, and how all the different populations of $\mathrm{T}$ cells are precisely regulated is an area of intensive investigation.

\section{Mechanisms of Action of Regulatory T Cells}

Both natural and adaptive regulatory $T$ cells need to be triggered by antigen to suppress other T cells. The antigenic specificites of this are largely unknown, but as mentioned above, it is thought that both autoantigens and, in the case of adaptive regulatory $\mathrm{T}$ cells, foreign antigens can trigger their function.

The targets of their suppression are ultimately other T cells, both $\mathrm{CD}^{+}$and $\mathrm{CD} 8^{+}$. This can be demonstrated in in-vitro cultures (57) as well as in in-vivo systems (6). It also appears that suppression can occur at both the priming stage of an immune response (13) and at the effector stage. In fact, at the effector stage, it may involve damage control, rather than induction of unresponsiveness (26). The regulated $\mathrm{T}$ cells are inhibited in their proliferation, as well as differentiation and cytokine production (57). It has been thought that regulatory $\mathrm{T}$ cells may block differentiation to- ward $\mathrm{T}_{\mathrm{H}} 1$, and skew responses toward a $\mathrm{T}_{\mathrm{H}} 2$ profile, however, both types of responses can be suppressed. The fact that $\mathrm{T}_{\mathrm{H}} 2$ responses can also be suppressed demonstrates that regulatory $\mathrm{T}$ cells have a potential to modulate airway hypersensitivity diseases (1). Even though regulatory T cells can directly inhibit other $\mathrm{T}$ cells, they can also do so indirectly by having an effect on dendritic cells. IL-10 producing adaptive regulatory $\mathrm{T}$ cells in particular downregulate levels of MHC class II and costimulatory molecule expression on dendritic cells, favoring an immature dendritic cell phenotype. Such immature dendritic cells fail to stimulate $\mathrm{T}$ cells optimally, but instead favor further development of more regulatory $\mathrm{T}$ cells (33).

Regulatory $\mathrm{T}$ cells are triggered by specific antigens, (in most cases unknown), but the antigenic specificity of suppression is variable. Adaptive regulatory T cells which are induced by i.v. administration of alloantigen mediate antigen specific suppression $(6,13)$ which can be transferred adoptively, and affect naive $T$ cells not exposed to the tolerizing antigen (infectious tolerance). In this case responses to other than the tolerizing antigen are maintained. However, other alternatives exist. Tolerance can spread to other antigens. In many cases, suppression is mediated in a bystander manner, meaning, that any specificity is suppressed (66). In a scenario called linked suppression, antigen specific suppression towards one antigen spreads to different antigens presented at the same site (same antigen presenting cell) (19). The molecular pathways of suppression are not completely understood. In-vitro, this phenomenon is contact dependent, especially for natural regulatory $\mathrm{T}$ cells, and in most cases does not involve cytokines. Cytokine dependent bystander regulatory $\mathrm{T}$ cell suppression has been demonstrated in-vivo, particularly by the adaptive types and in some natural regulatory $\mathrm{T}$ cell in in-vivo systems as well (52). For example, antibodies against IL-10 or its receptor can block colitis induced by cell transfer into SCID mice (28), $\mathrm{T}_{\mathrm{H}} 2$ immediate hypersensitivity (18), or bystander suppression in an EAE model (4). Similar effect has been observed with blocking TGF- $\beta$ in a $\mathrm{T}_{\mathrm{H}} 3$ mediated regulatory activity model (21). As far as natural regulatory $\mathrm{T}$ cells are concerned, they are mostly considered not to depend on cytokines for their regulation. In the in-vivo systems involving natural regulatory $\mathrm{T}$ cells where cytokines do play a role, the mechanism may be quite complex. It is not clear what cell actually produces the suppressive cytokine, and it is also possible that adaptive regulatory $\mathrm{T}$ cells are generated in these models as well $(6,11)$.

Regulation in most cases does not lead to a physical elimination of the regulated $\mathrm{T}$ cell. However, deletion can also occur in certain settings (40).

In order to try to understand regulatory $\mathrm{T}$ cell mediated suppression, certain things must be taken into consideration. Firstly, the in-vitro assays may not completely reflect the biology of in-vivo mediated regulation. Secondly, as already mentioned above, a lot of work on regulatory $\mathrm{T}$ cells has been carried out in experimental models with lympho- 
penia, where $\mathrm{T}$ cell homeostasis is normally under the influence of regenerative mechanisms. Since the natural $\mathrm{CD} 4{ }^{+} \mathrm{CD} 25^{+}$regulatory $\mathrm{T}$ cells are thought to have arisen under high affinity circumstances, they may perform better in their response to undergo regenerative homeostatic expansion, and in effect outcompete other T cells (7). Therefore, dissection of $\mathrm{T}$ regulatory cells in models without lymphopenia is especially important. Thirdly, recent experiments suggest that 'naturally occurring' regulatory $\mathrm{T}$ cells can either acquire characteristics of the adaptive regulatory $\mathrm{T}$ cells, or alternatively might facilitate their generation (11, 20).

\section{Aspects of clinical application}

Knowing the physiologic role of regulatory $\mathrm{T}$ cells in $\mathrm{T}$ cell homeostasis, the ability to utilize them in the clinic, as a treatment of autoimmune diseases, to suppress transplantation immune responses, and to suppress their action in other settings such as cancer and infectious diseases is highly desirable. In fact, it is already being attempted in different clinical protocols. Different strategies can be envisaged. One strategy is to induce or facilitate their activity in-vivo. This could be achieved by administering autoantigens in autoimmune diseases or alloantigens in the setting of transplantation. Such immunization generated regulatory T cell response should afford long-term protection, just as in vaccination, and because many of these cells can mediate bystander suppression, the antigen used to trigger them does not necessarily have to be identical with the antigen that drives the pathogenic response. In fact, many such protocols involving oral administration of autoantigens have been attempted in man in diseases such as multiple sclerosis (67), rheumatoid arthritis (60), uveitis (59), autoimmune thyroid disease (36), or type-1 diabetes (15). However, so far, they have failed to bring significant clinical benefit, perhaps due to the selection of patients with end-stage disease. The goal is to design a protocol with an optimal dose, timing and route of $\mathrm{Ag}$ administration to elicit a response skewed towards establishment and maintenance of a regulatory response, but not toward a pathogenic response. This could be attempted with regimen that include IL-10, IL-4 (23), or costimulation blockade (29) as response modifiers, while avoiding epitopes that could trigger autoaggressive cytotoxic lymphocyte (CTL) responses, and perhaps intranasal, rather than oral administration of antigen (43).

CD-3 specific monoclonal antibodies have been used for quite some time to induce tolerance in the context of transplantation, and even in established autoimmunity. In mouse models of autoimmune diabetes, administration of anti-CD3 monoclonal antibody can cure the disease by reestablishing tolerance to pancreatic $\beta$-cells (reviewed in 16). This could be due to different mechanisms, such as depletion of autoaggressive $\mathrm{T}$ cells, skewing of the $\mathrm{T}$ cell phenotype toward a $\mathrm{T}_{\mathrm{H}} 2$ profile, however it has been shown recently to involve as a major mechanism the generation of
$\mathrm{CD} 4^{+} \mathrm{CD} 25^{+}$regulatory T cells and TGF- $\beta$ (8). This approach has been successfully used in a Phase I trial in recent-onset diabetic patients (30), and is currently being tested in other clinical trials.

The other approach is to expand regulatory $\mathrm{T}$ cells invitro, and then administer them in-vivo. Such cells could be modified, for example by introducing genes for cell suicide, which would then enable their in-vivo control. Even though these cells are naturally unresponsive, there are reports where their in-vitro expansion has been successfully achieved. For example strongly proliferating human $\operatorname{Tr} 1$ cells can be induced in-vitro by treatment with anti-CD3 and anti$\mathrm{CD} 46 \mathrm{mAb}(42) . \mathrm{CD}^{+} \mathrm{CD} 25^{+}$regulatory $\mathrm{T}$ cells can also be expanded on DCs while they retain their suppressive effect (68).

It is also important to elucidate interaction of regulatory $\mathrm{T}$ cells with agents used for non-specific immunosuppression, since these drugs could interfere with the action of regulatory $\mathrm{T}$ cells.

\section{Acknowledgement}

I would like to thank Dr. Johanne Poudrier for many helpful discussions and suggestions.

\section{References}

1. Akbari O, Freeman GJ, Meyer EH et al. Antigen-specific regulatory T cells develop via the ICOS-ICOS-ligand pathway and inhibit allergen-induced airway hyperreactivity. Nat Med 2002;8:1024-32.

2. Almeida AR, Legrand N, Papiernik M, Freitas AA. Homeostasis of peripheral $\mathrm{CD} 4^{+} \mathrm{T}$ cells: IL-2R $\alpha$ and IL-2 shape a population of regulatory cells that controls CD4+ T-cell numbers. J Immunol 2002:169:4850-60.

3. Asano M, Toda M, Sakaguchi N, Sakaguchi S. Autoimmune disease as a consequence of developmental abnormality of a T-cell subpopulation. J Exp Med 1996; 184:387-96

4. Barrat FJ, Cua DJ, Boonstra A et al. In vitro generation of interleukin 10-producing regulatory $\mathrm{CD}^{+} \mathrm{T}$ cells is induced by immunosuppressive drugs and inhibited by T helper type 1 (Th1)- and Th2-inducing cytokines. J Exp Med 2002;195:603-16.

5. Bach JF. Immunotherapy of insulin-dependent diabetes mellitus. Curr Opin Immunol 2001;13(5):601-5.

6. Bach JF. Regulatory T cells unde Scrutiny. Nature Rev Immunol 2003;3:189-98.

7. Barthlott T, Kassiotis G, Stockinger B. T cell regulation as a side effect of homeostasis and competition. J Exp Med 2003;197(4):451-60.

8. Belghith M, Bluestone JA, Barriot S,Megret J, Bach JF, Chatenoud L. TGF- $\beta$-dependent mechanisms mediate restoration of self-tolerance induced by antibodies to CD3 in overt autoimmune diabetes. Nature Med 2003;9:1202-8.

9. Belkaid Y, Piccirillo CA, Mendez S, Shevach EM, Sacks DL. CD $4^{+} \mathrm{CD} 25^{+}$regulatory $\mathrm{T}$ cells control Leishmania major persistence and immunity. Nature 2002;420:502-7.

10. Bensinger SJ, Bandeira A, Jordan MS, Caton AJ, Laufer TM. Major histocompatibility complex class-II-positive cortical epithelium mediates the selection of $\mathrm{CD}^{+} \mathrm{CD} 25^{+}$immunoregulatory T cells. J Exp Med 2001;194:427-38.

11. Bluestone JA, Abbas AK. Natural versus adaptive regulatory T cells. Nature Rev Immunol 2003;3:253-7.

12. Boitard C, Yasunami R, Dardenne M, Bach JF. T cell-mediated inhibition of the transfer of autoimmune diabetes in NOD mice. J Exp Med 1989;169(5):1669-80.

13. Bushell A, Morris PJ, Wood KJ. Transplantation tolerance induced by antigen pretreatment and depleting anti-CD4 antibody depends on CD4+ T cell regulation during the induction phase of the response. Eur J Immunol 1995;25(9): 2643-96.

14. Chai JG, Bartok I, Chandler P et al. Anergic T cells act as suppressor cells in vitro and in vivo. Eur J Immunol 1999;29:686-92.

15. Chaillous $L$, Lefevre $H$, Thivolet $C$ et al. Oral insulin administration and residual beta-cell function in recent-onset type 1 diabetes: a multicentre randomized controlled trial. Diabete Insuline Orale group. Lancet 2000;356:545-9.

16. Chatenoud L. CD-3 specific antibody-induced active tolerance: from bench to bedside. Nature Rev Immunol 2003;3:123-32. 
17. Chen C, Lee WH, Yun P, Snow P, Liu CP. Induction of autoantigen-specific Th2 and $\operatorname{Tr} 1$ regulatory $\mathrm{T}$ cells and modulation of autoimmune diabetes. J Immuno 2003; 171(2):733-44

18. Cortez F, Hurst SD, Coffman RL, Groux H. T regulatory cells 1 inhibit a Th2-specific response in vivo. J Immunol 2000;165:4848-53.

19. Davies JD, Leong LY, Mellor A, Cobbold SP, Waldmann H. T-cell suppression in transplantation tolerance through linked recognition. J Immunol 1996;156: $3602-7$

20. Dieckmann D, Bruett CH, Ploettner H, Luty MB, Schuler G. Human CD4 $\mathrm{CD} 25^{+}$regulatory, contact-dependent $\mathrm{T}$ cells induce interleukin-10-producing, contact-independent type-1-like regulatory T cells. J Exp Med 2002;196:247-53.

21. Faria AM, Weiner HL. Oral tolerance: mechanisms and therapeutic applications. Adv Immunol 1999;73:153-264.

22. Fowell D, Mason D. Evidence that the T-cell repertoire of normal rats contain cells with the potential to cause diabetes. Characterization $\mathrm{CD}^{+}{ }^{+} \mathrm{T}$-cell subset that inhibits this autoimmune potential. J Exp Med 1993;177:627-36.

23. Garren H, Ruiz PJ,Watkins TA et al. Combination of gene delivery and D N A vaccination to protect from and reverse $\mathrm{T}_{\mathrm{H}} 1$ autoimmune disease via deviation to the $\mathrm{T}_{\mathrm{H}} 2$ pathway. Immunity $2001 ; 15: 15-22$.

24. Gavin MA, Clarke SR, Negrou A, Gallegos A, Rudensky A. Homeostasis and anergy of $\mathrm{CD}^{+}{ }^{+} \mathrm{CD} 25^{+}$suppressor T cells in vivo. Nat Immunol 2002;3:33-41.

25. Gershon RK, Kondo K. Cell interactions in the induction of tolerance: the role of thymic lymphocytes. Immunology 1970;18:723-37.

26. Gonzales A, Andre-Schmutz I, Camaud C, Mathis D, Benoist C. Damage control, rather than unresponsivenss, effected by protective $\mathrm{DX} 5^{+} \mathrm{T}$ cells in autoimmune diabetes. Nat Immunol 2001;2:1117-25.

27. Groux H. Type 1 T-regulatory cells: their role in the control of immune responses. Transplantation 2003;75(Suppl. 9):8S-12S.

28. Groux H, O'Garra A, Bigler M et al. A CD4+ T-cell subset inhibits antigen-specific T-cell responses and prevents colitis. Nature 1997;389:737-42.

29. Hanninen A, Martinez NR, Davey GM, Heath WR, Harrison LC. Transient blockade of CD40 ligand dissociates pathogenic from protective mucosal immunity. J Clin Invest 2002;109:261-7.

30. Herold KC, Hagopian W, Auger JA et al. Anti-CD3 monoclonal antibody in newonset type 1 diabetes mellitus. N Engl J Med 2002;346:1692-8.

31. Homan D, Holtz A, Bot A et al. Autoreactive CD4+ T cells protect from autoimmune diabetes via bystander suppression using the IL-4/Stat6 pathway. Immunity 1999:11(4):463-72.

32. Iwashiro M, Messer RJ, Peterson KE, Strommes IM, Sugie T, Hasenkrug KJ Immunosuppression by $\mathrm{CD}^{+}$regulatory $\mathrm{T}$ cells induced by chronic retroviral infection. Proc Natl Acad Sci USA 2001:98:9226-30.

33. Jonuleit H, Schmitt E, Schuler G, Knop J, Enk AH. Induction of interleukin 10 producing, nonproliferating $\mathrm{CD} 4^{+} \mathrm{T}$ cells with regulatory properties by repetitive stimulation with allogeneic immature human dendritic cells. J Exp Med 2000; 192:1213-22.

34. Jooss K, Gjata B, Danos O, von Boehmer H, Sarukhan A. Regulatory function of in vivo anergized CD4 ${ }^{+}$T cells. Proc Natl Acad Sci USA. 2001;98:8738-43.

35. Kemper C, Chan AC, Green JM, Brett KA, Murphy KM, Atkinson JP. Activation of human CD4+ cells with $\mathrm{CD} 3$ and CD46 induces a T-regulatory cell 1 phenotype. Nature 2003:421(6921):388-92.

36. Lee S, Scherberg N, DeGroot LJ. Induction of oral tolerance in human autoimmune thyroid disease. Thyroid 1998;8:229-34.

37. Lepault F, Gagnerault MC. Characterization of peripheral regulatory CD4+ $T$ cells that prevent diabetes onset in nonobese diabetic mice. J Immunol 2000;164(1): 240-7.

38. Liston A, Lesage S, Wilson J, Peltonen L, Goodnow CC. Aire regulates negative selection of organ-specific T cells. Nat Immunol 2003;4:350-4.

39. Lombardi G, Sidhu S, Batchelor R, Lechler R. Anergic T cells as suppressor cells in-vitro. Science 1994:264:1587-9.

40. Madakamutil LT, Maricic I, Sercary E, Kumar V. Regulatory T cells control autoimmunity in vivo by inducing apoptotic depletion of activated pathogenic lymphocytes. J Immunol 2003;170(6):2985-92.

41. Malek TR, Yu A, Vincek V, Scibelli P, Kong L. CD4 regulatory T cells prevent lethal autoimmunity in IL-2R $\beta$-deficient mice. Implications for the nonredundant function of IL-2. Immunity 2002;17:167-78.

42. Marshall NA, Vickers MA, Barker RN. Regulatory T cells secreting IL-10 dominate the immune response to EBV latent membrane protein 1. J Immunol 2003; 170:6183-9.

43. Metzler B, Wraith DC. Inhibition of experimental autoimmune encephalomyelitis by inhalation but not oral administration of the encephalitogenic peptide: in fluence of MHC binding affinity. Int Immunol 1993;5:1159-65.

44. McGuirk P, McCann C, Mills KH. Pathogen-specific T regulatory 1 cells induced in the respiratory tract by a bacterial molecule that stimulates interleukin 10 production by dendritic cells: a novel strategy for evasion of protective $\mathrm{T}$ helper type 1 responses by Bordetella pertussis. J Exp Med 2002;195:221-31.

45. McGuirk P, Mills KH. Pathogen-specific regulatory T cells provoke a shift in the Th1/Th2 paradigm in immunity to infectiozus diseases. Trends Immuno 2002;23(9):450-5.

46. Nishizuka Y, Sakakura T. Thymus and reproduction: sex-linked dysgenesia of the gonad after neonatal thymectomy in mice. Science 1969;166:753-5.
47. Poudrier J, Weng X, Kay DG, Hanna Z, Jolicoeur P. The AIDS-like disease of $\mathrm{CD} 4 \mathrm{C} / \mathrm{HIV} \mathrm{Tg}$ mice is associated with accumulation of immature $\mathrm{CD} 11 \mathrm{~b}^{\mathrm{Hi}}$ dendritic cells. J Virol (In Press)

48. Ramsdell F, Foxp3 and Natural Regulatory T Cells: Key to a Cell Lineage? Immunity 2003;19:165-8.

49. Sakaguchi S, Sakaguchi N, Asano M, Itoh M, Toda M. Immunologic self-tolerance maintained by activated $\mathrm{T}$ cells expressing IL-2 receptor $\alpha$-chains. J Immunol 1995:155:1151-64.

50. Schwartz RH. T Cell Anergy. Ann Rev Immunol 2003;21:305-34.

51. Shanmugam A, Copie-Bergman C, Hashim G et al. Healthy monozygous twins do not recognize identical T-cell epitopes on the myelin basic protein autoantigen. Eur J Immunol 1994:24:2299-303.

52. Seddon B, Mason D. Regulatory T cells in the control of autoimmunity: the essential role of transforming growth factor $-\beta$ and interleukin- 4 in the prevention of autoimmune thyroiditis in rats by peripheral $\mathrm{CD}^{+} \mathrm{CD} 45 \mathrm{RC}^{-c e l l s}$ and CD4 ${ }^{+}$CD8- thymocytes. J Exp Med 1999;189:279-88.

53. Singh B, Read S, Asseman C et al. Control of intestinal inflammation by regulatory T cells. Immunol Review 2001;182:190-200.

54. Stephens GL, Ignatowicz L. Decreasing the threshold for thymocyte activation biases CD4+ T cells toward a regulatory $(\mathrm{CD} 4+\mathrm{CD} 25+)$ lineage. Eur J Immuno 2003;33(5):1282-92.

55. Tanchot C, Barber DL, Chiodetti L, Schwartz RH. Adaptive tolerance of CD4+ $\mathrm{T}$ cells in vivo: multiple thresholds in response to a constant level of antigen presentation. J Immunol 2001;167:2030-9.

56. Teshima T, Reddy P, Liu C, Williams D, Cooke KR, Ferrara JLM. Impaired thymic negative selection causes autoimmune graft- versus-host disease. Blood 2003; 102:429-35.

57. Thornton AM, Shevach EM. CD4 ${ }^{+} \mathrm{CD} 25^{+}$immunoregulatory $\mathrm{T}$ cells suppress polyclonal $\mathrm{T}$ cell activation in vitro by inhibiting interleukin 2 production. J Exp Med 1998;188:287-96.

58. Thorstenson KM, Khoruts A. Generation of anergic and potentially immunoregulatory $\mathrm{CD} 25+\mathrm{CD} 4+\mathrm{T}$ cells in vivo after induction of peripheral tolerance with intravenous or oral antigen. J Immunol 2001;167:188-95.

59. Thurau SR, Diedrichs-Mohring M, Fricke H, Arbogast S, Wildner G. Molecular mimicry as a therapeutic approach for an autoimmune disease: oral treatment of uveitis patients with an MHC-peptide crossreactive with autoantigen-first results. Immunol Lett 1997;57:193-201

60. Trentham DE, Dynesius-Trentham RA, Orav EJ et al. Effects of oral administration of type II collagen on rheumatoid arthritis. Science 1993;261(5129): 1727-30.

61. Viney Jl, Mowat AM, O’Malley JM, Williamson E, Fanger NA. Expanding dendritic cells in vivo enhances the induction of oral tolerance. J Immunol 1998; 160(12):5815-25

62. vonHerrath MG, Harrison LC. Antigen-induced regulatory T cells in autoimmunity. Nature Rev Immunol 2003;3:223-32.

63. Wakkach A, Fournier N, Brun V, Breittmayer JP, Cortez F, Groux H. Characterization of dendritic cells that induce tolerance and $\mathrm{T}$ regulatory 1 cell differentiation in vivo. Immunity 2003;18:605-17.

64. Weiner HL. Induction and mechanism of action of transforming growth factorbeta-secreting Th3 regulatory cells. Immunol Rev 2001;182:207-14.

65. Weiner HL. The mucosal milieu creates tolerogenic dendritic cells and $T(R) 1$ and $\mathrm{T}(\mathrm{H}) 3$ regulatory cells. Nat Immunol 2001;2(8):671-2.

66. Weiner HL, Friedman A, Miller A et al. Oral tolerance: immunologic mechanisms and treatment of animal and human organ-specific autoimmune diseases by oral administration of autoantigens. Annu Rev Immunol 1994:12:809-37.

67. Weiner HL, Mackin GA, Matsui M et al. Double-blind pilot trial of oral tolerization with myelin antigens in multiple sclerosis. Science 1993;259(5099):1321-4.

68. Yamazaki S, Iyoda T, Tarbell K et al. Direct expansion of functional CD25+ CD4+ regulatory T cells by antigen-processing dendritic cells. J Exp Med 2003; 198(2):235-47.

69. Zhang ZJ, Davidson L, Eisenbarth G, Weiner HL. Suppression of diabetes in nonobese diabetic mice by oral administration of porcine insulin. Proc Natl Acad Sci USA 1991;88(22):10252-6.

70. Zheng SG, Gray JD, Ohtsuka K, Yamagiwa S, Horwitz DA. Generation ex vivo of TGF-beta-producing regulatory $\mathrm{T}$ cells from $\mathrm{CD} 4+\mathrm{CD} 25-$ precursors. J Immunol 2002;169(8):4183-9.

Submitted August 2003.

Accepted September 2003.

MUDr. Pavel Chrobák

Research Associate,

110 Ave des Pins Ouest,

Montreal, Quebec, $\mathrm{H} 2 \mathrm{~W} 1 \mathrm{R} 7$,

Canada.

e-mail: chrobakp@ircm.qc.ca 